\title{
An Examination of Academic Procrastination Behavior In Pre-service
}

\section{Teachers}

Gonca EREN ${ }^{1}$, Dilek YALIZ SOLMAZ ${ }^{2}$

\begin{abstract}
It is important to identify academic procrastination behaviours disrupting the educational life of students, it is also important to determine the academic procrastination tendencies and underlying causes in teachers and pre-service teachers, who are an inseparable part of the education environment. The aim of this research was to examine several variables of academic procrastination behaviour in a group of 113 pre-service teachers studying in the Physical Education and Sports Teaching Department of Anadolu University. The Academic Procrastination Inventory developed by Aitken (1982) and adapted to Turkish by Balkis (2006) was used in the study. In the analyses of the data, arithmetic means, standard deviation, t-test and ANOVA analysis were used. According to the results obtained, no significant difference was determined between the levels of academic procrastination of the pre-service teachers according to gender, year of study, the department selected for study, parental level of education or the perceptions of academic success. When the times that the pre-service teachers preferred to study lessons were examined, a significant difference was determined, with those preferring to work in the evening showing a lesser tendency for academic procrastination.
\end{abstract}

Keywords: Procrastination, academic procrastination, physical education and sports teaching, preservice teachers

\footnotetext{
${ }^{1}$ Eskişehir Teknik Üniversitesi, Spor Bilimleri Fakültesi, Beden Eğitimi ve Spor Eğitimi Bölümü, e-mail: goncaeren@eskisehir.edu.tr ORCID: 0000-0001-9787-9098

${ }^{2}$ Eskişehir Teknik Üniversitesi, Spor Bilimleri Fakültesi, Beden Eğitimi ve Spor Eğitimi Bölümü, e-mail: dilekyaliz@eskisehir.edu.tr ORCID: 0000-0003-0497-215X
} 
AJESI - Anadolu Journal of Educational Sciences International, 2019; 9(2): 666-682

DOI: 10.18039/ajesi.577733

\section{Introduction}

Many factors affect human behaviours. These factors can be social, cultural, physical, psychological or economic factors. In the modern world there are constantly increasing technological developments and scientific advances and these cause changes in the behaviours and attitudes in the life path of individuals. Increasing technological developments present individuals with a greater number and more rapid sources of communication and thereby increase the pace of daily life.

Just as an acceleration in daily life can provide advantages in both private and working life, it may also be a reason for accumulated tasks and tasks that require completion, thereby placing the individual in a disadvantageous situation. Tasks with accumulated responsibilities in particular increase the tendency of the individual to procrastination and cause them to exhibit procrastination behaviour. Although there have been intense studies by modern psychologists and researchers on these procrastination behaviours and possible reasons, Steel (2007) reported that there were many unknowns related to the tendency to procrastinate despite the increased interest in this subject.

The procrastination tendency was defined by Grecco (1984) as the potential of a person to delay completion of an important task or job without showing a valid reason, and as a result of a procrastination tendency, the majority showed insufficient performance (Ferrari, O’Callaghan, \& Newbegin, 2005; Solomon \& Rothblum, 1984). Moreover, procrastination behaviour, which was identified as extremely widespread in adults, was determined to lead to stress and other diseases (Dewitte \& Schouwenburg, 2002; Fritzsche, Young, \& Hickson, 2003; Tice \& Baumeister, 2018). Hammer and Ferrari (2002) reported that $20 \%$ of adults displayed chronic procrastination behaviour in daily tasks and responsibilities, while other 
AJESI - Anadolu Journal of Educational Sciences International, 2019; 9(2): 666-682 DOI: 10.18039/ajesi.577733

researchers determined that $70 \%-95 \%$ of high school students had a tendency to academic procrastination (Ellis \& Knaus, 1977; Steel, 2007).

Although academic procrastination is examined in literature under the heading of general procrastination, Senecal, Koestner and Vallerand (1995) defined this as individuals not starting these tasks until they experience a high level of stress associated with not having fulfilled the necessary academic tasks at the right time. According to Scher and Osterman (2002), academic procrastination is a barrier to academic success, a significant source of stress for the student and a factor reducing the amount and quality of what is learned. In addition, when attention is drawn to the intensity of academic procrastination in university environments, it has been concluded that there is a correlation between the level of academic procrastination and low levels of self-organisation, academic self-sufficiency and selfconfidence, and high levels of anxiety, stress and illness. (Ferrari et al., 2005; Howell, Watson, Powell, \& Buro, 2006; Schraw, Wadkins, \& Olafson, 2007; Tice \& Baumeister, 2018; Wolters, 2003).

In previous studies of university students, a statistically significant positive relationship has been determined between anxiety and academic procrastination tendency (Aitken, 1982; Beswick, Rothblum, \& Mann, 1988; Senecal, Koestner \& Vallerand, 1995; Solomon \& Rothblum, 1984; as cited in, Balkis, 2006). Accordingly, it has been reported that as the problem of academic procrastination increased, so university students experienced severe psychological and economic losses, academic success decreased and thereby the period in education was prolonged (Turkum, 2007).

Just as it is important to identify academic procrastination behaviours disrupting the educational life of students, it is also important to determine the academic procrastination tendencies and underlying causes in teachers and pre-service teachers, who are an inseparable 
AJESI - Anadolu Journal of Educational Sciences International, 2019; 9(2): 666-682 DOI: 10.18039/ajesi.577733

part of the education environment. Teachers spend the greater part of their day with the adults of the future and as a significant part of educational life have a role in educating them to be useful members of society. Furthermore, as examples to the students, the attitudes, behaviour and habits displayed by teachers play a role in shaping the behaviours of students.

Balkis (2006) emphasised that teachers should be equipped with professional skills such as timely and effective planning, self-organisation and non-procrastination of academic duties. Therefore, to train more successful teachers, it is important to firstly determine the levels of academic procrastination tendencies of pre-service teachers who will become the teachers of the future and to investigate the reasons underlying these tendencies.

The aim of this study was to examine several variables of academic procrastination behavours of pre-service teachers studying in the Physical Education and Sports Teaching Department of Anadolu University.

\section{Material and Method}

\section{Research model}

This research was designed as a survey model. According to Karasar (2015), the survey model is "a model that examines only one variable or examines variables separately one by one" within general survey models. As the aim of this research was to examine the relationships between the academic procrastination tendency and some variables of preservice teachers, it was applied in the framework of a research survey model. 
AJESI - Anadolu Journal of Educational Sciences International, 2019; 9(2): 666-682

DOI: 10.18039/ajesi.577733

\section{Research Group}

The study group for this research was formed of students in the Physical Education and Sports Teaching Department of Anadolu University. The group included a total of 113 students from the first, second, third and fourth years of the Physical Education and Sports Teaching Department in the academic year 2016-2017. The study group comprised 55 (48.7\%) females and $58(51.3 \%)$ males.

\section{Data Collection Tools}

To measure the academic procrastination tendencies of the pre-service teachers in the study, the Aitken Procrastination Inventory was used, and to obtain personal information about the students, a demographic information form was created and used.

\section{Personal information form:}

The Personal Information Form that was developed for this study included questions related to gender, year of study, reasons for selecting to study in the department, parental level of education, time of day preferred for lesson study and perceived academc success.

\section{Academic procrastination inventory:}

To determine the tendency for procrastination of academic duties of the pre-service teachers, the Academic Procrastination Inventory (API) developed by Aitken (1982) and adapted to Turkish by Balkis (2006) was used. The API is formed of 16 items in a single dimension and each item is answered with a 5-point Likert-type scale from correct $=5$ to incorrect $=1$. Item numbers $2,4,9,10,12,13,14,15$ and 16 were reverse scored. High total points indicate a higher procrastination tendency. The internal consistency coefficient of the 
AJESI - Anadolu Journal of Educational Sciences International, 2019; 9(2): 666-682 DOI: 10.18039/ajesi.577733

scale was found to be $\alpha=0.89$, and the Pearson correlation was determined as $r=0.87$, $\mathrm{p}<0.001$ in the analysis applied for test-retest reliability. Factor analysis was applied to test the structure validity of the scale. As a result of the analyses, it was seen that $38.38 \%$ of the factor loadings were collected on a factor formed with 6.14 Eigen value. Thus it was reported that the API was a valid and reliable scale that could be used in the determination of the academic procrastination tendency of the students (Balkis 2006). As a result of the repeated reliability analysis in this study, reliability of the scale was determined as 0.88 .

\section{Data Collection and Analysis}

To analyse the data obtained in the study, normal distribution was examined according to the academic procrastination tendency points of all the participants. Skewness and kurtosis coefficients were examined in the assessment of normal distribution. The results obtained showed normal distribution of the data. To then decide which tests could be used in the data analysis, the homogeneity of the data was examined and confirmed (Levene $>0.05$ ). Data analyses were performed on the computer with the points calculated as arithmetic mean \pm standard deviation (SD) values. T-test and One-Way Variance Analysis (ANOVA) were also applied to the data. To determine the source of a significant difference between groups, the multiple comparison LSD test was used. A value of $p<0.05$ was accepted as statistically significant.

\section{Findings}

The results obtained from the analysis of the data of the academic procrastination levels of the pre-service teachers in the Physical Education and Sports Teaching Department are presented in the tables and interpreted below. 
AJESI - Anadolu Journal of Educational Sciences International, 2019; 9(2): 666-682

DOI: 10.18039/ajesi.577733

Table 1

The t-test Results of the Academic Procrastination Points of the Pre-service Teachers according to Gender

\begin{tabular}{lcccccc}
\hline \hline & & $\mathrm{N}$ & Mean & $\mathrm{SD}$ & $\mathrm{t}$ & $\mathrm{p}$ \\
\hline \multirow{3}{*}{$\begin{array}{l}\text { Academic Procrastination } \\
\text { Tendency }\end{array}$} & Female & 55 & 37.87 & 9.72 & & \\
\cline { 2 - 5 } & Male & 58 & 39.97 & -1.116 & .27 \\
\hline \hline
\end{tabular}

The t-test and standard deviation points related to the academic procrastination tendencies of the pre-service teachers are shown in Table 1 . The mean points obtained were 39.97 for male students and 38.87 for female students, showing a higher tendecy of males for academic procrastination. According to the Independent Samples t-test, no statistically significant difference was determined between the genders in respect of academic procrastination tendency $\left(\mathrm{t}_{(-1.116)} ; \mathrm{p}>0.05\right)$.

Table 2

ANOVA Test Results related to the Academic Procrastination Tendency Points according to the year of study

\begin{tabular}{lccccccc}
\hline \hline & $\mathrm{N}$ & Mean & SD & F & $\mathrm{p}$ \\
\hline \multirow{3}{*}{$\begin{array}{l}\text { Academic } \\
\text { Tendency }\end{array}$} & Procrastination & 1st year & 23 & 39.91 & 9.01 & & \\
\cline { 2 - 6 } & 2nd year & 31 & 36.94 & 9.58 & \multirow{2}{*}{0.650} & 0.59 \\
\cline { 2 - 6 } & 3rd year & 30 & 39.03 & 8.80 & & \\
\cline { 2 - 6 } & 4th year & 29 & 40.24 & 12.19 & & \\
\hline \hline
\end{tabular}

The ANOVA test results related to the academic procrastination tendency of the preservice teachers according to the year of study are shown in Table 2. No statistically significant difference was seen in the levels of academic procrastination according to the year 
AJESI - Anadolu Journal of Educational Sciences International, 2019; 9(2): 666-682

DOI: 10.18039/ajesi.577733

of study $\left(\mathrm{F}_{(0.650)} ; \mathrm{p}>0.05\right)$. The year of study was not determined to have any effect on the procrastination behaviour of the pre-service teachers.

Table 3

ANOVA Test Results related to the Academic Procrastination Tendency Points according to the reasons for having selected the department of study

\begin{tabular}{|c|c|c|c|c|c|c|}
\hline & & $\mathrm{N}$ & Ortalama & SS & F & $\mathrm{p}$ \\
\hline \multirow{3}{*}{$\begin{array}{l}\text { Academic } \\
\text { Procrastination } \\
\text { Tendency }\end{array}$} & $\begin{array}{l}\text { I wished to study in } \\
\text { this department; I am } \\
\text { happy now }\end{array}$ & 99 & 38.47 & 9.94 & \multirow{3}{*}{0.978} & \multirow{3}{*}{0.38} \\
\hline & $\begin{array}{l}\text { I wished to study in } \\
\text { this department, but I } \\
\text { am not happy now }\end{array}$ & 10 & 41.60 & 10.75 & & \\
\hline & $\begin{array}{l}\text { I did not wish to study } \\
\text { in this department, and } \\
\text { I am not happy now }\end{array}$ & 4 & 44.00 & 8.40 & & \\
\hline
\end{tabular}

The ANOVA test results related to the academic procrastination tendency of the preservice teachers according to the selection of the department where they are studying are shown in Table 3. No statistically significant difference was seen in the levels of academic procrastination according to the selection of the department where they are studying $\left(\mathrm{F}_{(0.978)}\right.$; $\mathrm{p}>0.05$ ). The selection of the department of study was not determined to have any effect on the procrastination behaviour of the pre-service teachers. 
AJESI - Anadolu Journal of Educational Sciences International, 2019; 9(2): 666-682

DOI: 10.18039/ajesi.577733

Table 4

ANOVA Test Results related to the Academic Procrastination Tendency Points according to the Maternal Level of Education

\begin{tabular}{|c|c|c|c|c|c|c|}
\hline & & $\mathrm{N}$ & Mean & $\mathrm{SD}$ & $\mathrm{F}$ & $\mathrm{p}$ \\
\hline \multirow{4}{*}{$\begin{array}{l}\text { Academic } \\
\text { Procrastination } \\
\text { Tendency }\end{array}$} & Primary School & 55 & 39.16 & 10.68 & \multirow{4}{*}{0.227} & \multirow{4}{*}{0.88} \\
\hline & Middle School & 19 & 37.31 & 9.66 & & \\
\hline & High School & 28 & 39.18 & 8.49 & & \\
\hline & University & 11 & 40.09 & 11.30 & & \\
\hline
\end{tabular}

The ANOVA test results related to the academic procrastination tendency of the preservice teachers according to the maternal level of education are shown in Table 4 . No statistically significant difference was seen in the levels of academic procrastination according to the level of maternal education $\left(\mathrm{F}_{(0.227)} ; \mathrm{p}>0.05\right)$. The level of maternal education was not determined to have any effect on the procrastination behaviour of the pre-service teachers.

Table 5

ANOVA Test Results related to the Academic Procrastination Tendency Points according to the Paternal Level of Education

\begin{tabular}{lllllll}
\hline \hline & & $\mathrm{N}$ & Mean & $\mathrm{SD}$ & $\mathrm{F}$ & $\mathrm{p}$ \\
\hline \multirow{3}{*}{$\begin{array}{l}\text { Academic } \\
\begin{array}{l}\text { Procrastination } \\
\text { Tendency }\end{array}\end{array}$} & Primary School & 36 & 37.47 & 11.61 & \\
\cline { 2 - 5 } & Middle School & 21 & 39.33 & 10.35 & \\
\cline { 2 - 5 } & High School & 39 & 40.33 & 8.42 & 0.634 \\
\cline { 2 - 5 } & University & 17 & 38.95 & 9.44 & \\
\hline \hline
\end{tabular}

The ANOVA test results related to the academic procrastination tendency of the preservice teachers according to the paternal level of education are shown in Table 5. No statistically significant difference was seen in the levels of academic procrastination according 
AJESI - Anadolu Journal of Educational Sciences International, 2019; 9(2): 666-682

DOI: 10.18039/ajesi.577733

to the level of paternal education $\left(\mathrm{F}_{(0.534)} ; \mathrm{p}>0.05\right)$. The level of paternal education was not determined to have any effect on the procrastination behaviour of the pre-service teachers.

Table 6

ANOVA Test Results related to the Academic Procrastination Tendency Points according to the preferred time for study lessons

\begin{tabular}{|c|c|c|c|c|c|c|c|}
\hline & & $\mathrm{N}$ & mean & SD & $\mathrm{F}$ & $\mathrm{p}$ & difference \\
\hline \multirow{5}{*}{$\begin{array}{l}\text { Academic } \\
\text { Procrastination } \\
\text { Tendency }\end{array}$} & Morning & 24 & 39.71 & 11.95 & \multirow{5}{*}{2.677} & \multirow{5}{*}{0.03} & \multirow{5}{*}{$\mathrm{c}<\mathrm{b}, \mathrm{d}, \mathrm{e}$} \\
\hline & Afternoon & 18 & 41.33 & 8.45 & & & \\
\hline & Evening & 37 & 35.14 & 8.85 & & & \\
\hline & Night & 26 & 40.08 & 9.55 & & & \\
\hline & $\begin{array}{l}\text { Very late hours } \\
\text { (after 2400) }\end{array}$ & 8 & 45.25 & 8.78 & & & \\
\hline
\end{tabular}

The ANOVA test results related to the academic procrastination tendency of the preservice teachers according to the preferred time for studying lessons are shown in Table 6 . A statistically significant difference was seen in the levels of academic procrastination according to the preferred time for studying lessons $\left(\mathrm{F}_{(2.677)} ; \mathrm{p}<0.05\right)$. This showed that the variable of preferred time for studying lessons had a significant effect on the procrastination behaviour of the pre-service teachers. The LSD test was applied to determine from which group the difference originated. According to the results, a significant difference was seen in the levels of academic procrastination between the students who preferred working in the evening and those who preferred the afternoon, the night and very late hours. Those who preferred studying lessons in the evening demonstrated lower levels of academic procrastination.

Table 7 
AJESI - Anadolu Journal of Educational Sciences International, 2019; 9(2): 666-682

DOI: 10.18039/ajesi.577733

ANOVA Test Results related to the Academic Procrastination Tendency Points according to the Perceptions of Academic Success

\begin{tabular}{lllllll}
\hline \hline & & $\mathrm{N}$ & Mean & SD & F & $\mathrm{p}$ \\
\hline $\begin{array}{l}\text { Academic } \\
\begin{array}{l}\text { Procrastination } \\
\text { Tendency }\end{array}\end{array}$ & Poor & 7 & 41.86 & 12.23 & & \\
\cline { 2 - 5 } & Moderate & 84 & 39.40 & 9.94 & 1.181 & 0.31 \\
\cline { 2 - 5 } & Good & 22 & 36.95 & 9.30 & & \\
\hline \hline
\end{tabular}

The ANOVA test results related to the academic procrastination tendency of the preservice teachers according to the perceptions of academic success are shown in Table 7. No statistically significant difference was seen in the levels of academic procrastination according to the perceptions of academic success $\left(\mathrm{F}_{(1.181)} ; \mathrm{p}>0.05\right)$. The perception of academic success was not determined to have any effect on the procrastination behaviour of the pre-service teachers.

\section{Discussion and Recommendations}

The results related to the independent variables of the research are discussed below in the light of previous publications in literature and recommendations are presented that could be used by researchers in future studies.

When the API points obtained by the pre-service teachers were examined according to gender, it was seen that the points of both the males and females were below average, although the female pre-service teachers had a slightly lower tendency for academic procrastination than the males. The difference was not statistically significant and thus the variable of gender was not determined to have a significant effect on the levels of academic procrastination. This result was in parallel with the findings of previous studies in literature that have examined the relationship between gender and the tendency for academic 
AJESI - Anadolu Journal of Educational Sciences International, 2019; 9(2): 666-682 DOI: 10.18039/ajesi.577733

procrastination (Watson, 2001; Hess, Sherman, and Goodman, 2000; Haycock, McCarty, and Skay, 1998; Ferrari, 1991; Johnson and Bloom, 1995; Effert and Ferrari, 1989; Rothblum, Solomon, and Murakabi, 1986; Solomon and Rothblum, 1984). In a study of pre-service teachers by Balkıs, Duru, Bulus and Duru (2008) results were reported that male students showed a greater tendency for academic procrastination than female students. In this respect, that higher mean points of academic procrastination of the males compared to the females were found in the current study showed a similarity to literature.

However, there was no significant difference between the academic grade levels and academic procrastination in pre-service teachers. While Balkis (2006) determined a relationship between the grade levels and academic procrastination, Cetin (2009) found no relationship between the two variables. According to this result that there was no significant difference in grade levels and academic procrastination of the pre-service teachers in the first, second, third and fourth grades of bachelor degree. It is showed that there was a homogenous structure in the group of pre-service teachers. At the same time this can be explained by the habit structures of indivduals having been shaped to a great degree in the university years and the time interval is not wide enough to provide a change at a significant level.

When the academic procrastination points of the pre-service teachers were examined in respect of their selection of the department where they were studying, there was seen to be no statistically significant difference. However, the API points of the pre-service teachers who gave the response of "I wished to study in this department; I am happy now", were seen to be lower than those who stated, "I wished to study in this department, but I am not happy now" and "I did not wish to study in this department and I am not happy now". Pre-service teachers who have selected the department because of somebody else's wishes and who are not happy with the department may find themselves unsuited to the profession and may not have 
AJESI - Anadolu Journal of Educational Sciences International, 2019; 9(2): 666-682 DOI: 10.18039/ajesi.577733

sufficient motivation to undertake the academic duties in the scope of this education. This could then result in a tendency to demonstrate academic procrastination.

In the examination of the levels of education of the parents of the pre-service teachers, there was not found to be any significant effect on the levels of academic procrastination. However, the pre-service teachers whose mother had a middle school level of education and whose father had primary school level had lower tendencies for academic procrastination than those with parents at other levels of education. Yildiz (2015) stated that this could be due to worries that their parents had not fulfilled their own dreams. It can also be said that even if there is no obvious pressure from the parents, when the subject of education is seen to be important in the family and perhaps the parents closely monitor the child's lessons and success, less academic procrastination behaviour is seen.

When the academic procrastination behaviour was examined in respect of the preferred times for studying, there was determined to be a lesser tendency for academic procrastination by those who preferred studying lessons in the evening compared to those who preferred to study in the afternoon, at night, or at very late hours. In other words, the preservice teachers who preferred to study lessons in the afternoon, at night and at very late hours showed greater academic procrastination behaviour than those who preferred to study in the evening.

When the tendencies for academic procrastination were examined according to the perceptions of the pre-service teachers of their level of academic success, there was not seen to be any statistically significant difference. Thus it can be said that the perceived level of academic success had no effect on the academic procrastination tendency. This finding is in contrast to some previous results in literature, as Balkis et al (2008) reported that academic procrastination had a negative effect on academic success, and a negative relationship was determined between academic procrastination behaviour and academic success. 
AJESI - Anadolu Journal of Educational Sciences International, 2019; 9(2): 666-682 DOI: 10.18039/ajesi.577733

In another study that examined academic success and the tendency for academic procrastination, Di Paula and Campbell (2002) emphasised that a high level of academic procrastination had a role in low levels of academic success and low self-confidence. Di Paula and Campbell (2002) also stated that individuals with low self-confidence had difficulty improving their behaviour compared with individuals with a high level of self-confidence, and it was reported that these individuals, when faced with a situation of failure, would have a greater tendency to procrastinate and leave work incomplete rather than making an effort.

In conclusion, not every dimension of academic procrastination behaviour has been revealed. There are still differences of opinion in literature about some variables such as gender and factors that affect academic procrastination behaviour. Therefore, to reduce these differences of opinion, there is a need for further studies to determine the variables and factors affecting academic procrastination tendency.

\section{References}

Aitken, M. E. (1982). A personality profile of the college student procrastinator (Unpublished Doctoral Dissertation). University of Pittsburgh.

Balkıs, M (2006). Öğretmen adaylarının davranışlarındaki erteleme eğilimlerinin düşünme ve karar verme tarzlart ile ilişkisinin incelenmesi (Unpublished doctoral dissertation). Eğitim Bilimleri Enstitüsü, D.E.U.B.E.F, İzmir.

Balkıs, M., Duru, E., Buluş, M. ve Duru, S. (2008). Üniversite öğrencilerinde akademikerteleme eğiliminin çeşitli değişkenler açısından incelenmesi. Ege Üniversitesi Ĕ̈itim Fakültesi Dergisi, 7(2), 59-75

Beswick, G., Rothblum, E. D., \& Mann, L. (1988). Psychological antecedents of student procrastination. Australian Psychologist, 23(2), 207-217. 
AJESI - Anadolu Journal of Educational Sciences International, 2019; 9(2): 666-682 DOI: 10.18039/ajesi.577733

Çetin, Ş. (2009). Eğitim fakültesi öğrencilerinin akademik erteleme davranışlarına ilişkin görüşlerinin incelenmesi. Gazi Üniversitesi Endüstriyel Sanatlar Eğitim Fakültesi Dergisi, 25: 1-7.

Dewitte, S., \& Schouwenburg, H. C. (2002). Procrastination, temptations, and incentives: The struggle between the present and the future in procrastinators and the punctual. European Journal of Personality, 16(6), 469-489.

Di Paula, A., \& Campbell, J. (2002). Self-esteem and persistence in the face of failure. Journal of Personality \& Social Psychology, 83, 711-724.

Effert, B., R. ve Ferrari, J. R. (1989). Decisional procrastination: Examining personality correlates. Journal of Social Behavior \& Personality, 4, 151-156

Ellis, A. ve Knaus, W. J. (1977). Overcoming procrastination. New York: Signet Books.

Ferrari, J. R. (1991). Self-handicapping by procrastinators: Protecting self-esteem, socialesteem, or both?. Journal of Research in Personality, 25(3), 245-261.

Ferrari, J. R., O'Callaghan, J., \& Newbegin, I. (2005). Prevalence of procrastination in the United States, United Kingdom, and Australia: arousal and avoidance delays among adults. North American Journal of Psychology, 7(1).

Fritzsche, B. A., Young, B. R., \& Hickson, K. C. (2003). Individual differences in academic procrastination tendency and writing success. Personality and Individual Differences, $35(7), 1549-1557$.

Grecco, P. R. (1984). A cognitive-behavioral assessment of problematic academic procrastination: development of a procrastination self- statement inventory. (Unpublished PHD), California School of Professional Psychology - Fresno.

Hammer, C. A., \& Ferrari, J. R. (2002). Differential incidence of procrastination between blue and white-collar workers. Current Psychology, 21(4), 333-338. 
AJESI - Anadolu Journal of Educational Sciences International, 2019; 9(2): 666-682 DOI: 10.18039/ajesi.577733

Haycock, L. A., McCarthy, P., \& Skay, C. L. (1998). Procrastination in college students: The role of self-efficacy and anxiety. Journal of Counseling \& Development, 76(3), $317-$ 324.

Hess, B., Sherman, M. F., \& Goodman, M. (2000). Eveningness predicts academic procrastination: The mediating role of neuroticism. Journal of Social Behavior and Personality, 15(5), 61.

Howell, A. J., Watson, D. C., Powell, R. A., \& Buro, K. (2006). Academic procrastination: The pattern and correlates of behavioural postponement. Personality and Individual Differences, 40(8), 1519-1530.

Johnson, J. L., \& Bloom, A. M. (1995). An analysis of the contribution of the five factors of personality to variance in academic procrastination. Personality and Individual Differences, 18(1), 127-133.

Karasar, N. (2015). Scientific method.

Rothblum, E. D., Solomon, L. J., \& Murakami, J. (1986). Affective, cognitive, and behavioral differences between high and low procrastinators. Journal of Counseling Psychology, $33(4), 387$.

Scher, S. J., \& Osterman, N. M. (2002). Procrastination, conscientiousness, anxiety, and goals: Exploring the measurement and correlates of procrastination among school-aged children. Psychology in the Schools, 39(4), 385-398.

Schraw, G., Wadkins, T., \& Olafson, L. (2007). Doing the things, we do: A grounded theory of academic procrastination. Journal of Educational Psychology, 99(1), 12.

Senécal , C., Koestner, R. and Vallerand, R. J. (1995). Self-regulation and academic procrastination. Journal of Social Psychology, 135(1), 607-619.

Solomon, L. J.ve Rothblum, E. D. (1984). Academic procrastination: Frequency and cognitive-behavioral correlates. Journal of Counseling Psychology, 31, 503-509 
AJESI - Anadolu Journal of Educational Sciences International, 2019; 9(2): 666-682 DOI: 10.18039/ajesi.577733

Steel, P. (2007). The nature of procrastination: A meta-analytic and theoretical review of quintessential self-regulatory failure. Psychological Bulletin, 133(1), 65.

Tice, D. M., \& Baumeister, R. F. (2018). Longitudinal study of procrastination, performance, stress, and health: The costs and benefits of dawdling. In Self-Regulation and SelfControl (pp. 299-309). Routledge.

Türküm, S. (2007). Üniversite gençliğine yönelik psikolojik danışma ve rehberlik hizmetleri. Gelişen Psikolojik Danışma ve Rehberlik, (SS: 201-218). Ankara: Nobel Yayın Dağıtım.

Watson, D. C. (2001). Procrastination and the five-factors model: A facet level analysis. Personality and Individual Differences, 30, 149-158.

Wolters, C. A. (2003). Understanding procrastination from a self-regulated learning perspective. Journal of Educational Psychology, 95(1), 179.

Yildiz, G. F. (2015). Üniversite ögrencilerinin genel erteleme düzeyleri ile akademik erteleme düzeyleri ilişkisinin incelenmesi (Unpublished master dissertation). Fatih Üniversitesi Sosyal Bilimler Enstitüsü. İstanbul. 